\title{
РЕЗУЛЬТАТИ ВПРОВАДЖЕННЯ ПРОГРАМИ ФІЗИЧНОЇ ТЕРАПІЇ ЗА ПОКАЗНИКАМИ ОСІБ ПОХИЛОГО ВІКУ ІЗ ХВОРОБОЮ АЛЬЦГЕЙМЕРА
}

\author{
О.О. Беспалова, Ю.О. Лянной, Т.В. Бугаєнко, О.В. Лянна, Н.Б. Авраменко
}

Сумський державний педагогічний університет імені А.С. Макаренка, кафедра здоров'я, фізичної терапії, реабілітаиії та ерготерапії,

м. Суми, Україна,

ORCID ID:0000-0002-0081-6021,e-mail:i-ozon777@bigmir.net,

ORCID ID: 0000-0003-2332-8794,e-mail:lyo_ifk@ukr.net,

ORCID ID: 0000-0003-3745-0593,e-mail:bugaenkotv@ukr.net,

ORCID ID:0000-0002-4467-7166,e-mail:lann_olga@ukr.net,

ORCID ID: 0000-0002-1894-7345, e-mail:avram2104@gmail.com

Резюме. Деменція - це ушкодження мозку внаслідок різноманітних травм та захворювань, яке призводить до стійких порушень когнітивних та рухових функцій. Одним із дегенеративних неврологічних захворювань, яке спричиняє деменцію, є хвороба Альцгеймера. 3 метою ефективного реабілітаційного втручання необхідна професійна допомога фахівців мультидисциплінарної команди, де фахівцям з фізичної терапії, ерготерапії належить одне із провідних місць. Завданнями фізичної терапії, ерготерапії щодо осіб з хворобою Альцгеймера є: підвищення рівня їх фізичної активності, розвиток головних фізичних якостей, збереження побутових рухових навичок та покращення психоемоційного стану. 3 цією метою була розроблена, науково обгрунтована та впроваджена у діяльність Комунальної установи Сумської обласної ради «Лебединський психоневрологічний інтернат» комплексна програма фізичної терапії, ерготерапії, до якої було включено ранкову гігієнічну гімнастику, лікувальну гімнастику, працетерапію та лікувальну дозовану ходьбу. Реалізація авторської програми відбувалася упродовж 5 місяців, що було обумовлено науково обгрунтованими даними про те, що поліпшення якості життя осіб з хворобою Альцгеймера достовірно може покращитися лише через 3-6 місяців після початку реабілітаційних заходів. У дослідженні використовувалися методи: контент-аналіз медичної документації; педагогічні - спостереження, медико-біологічні: шкала MMSE, шкала PAINAD, шкала «Оцінка рухової активності у осіб похилого віку»; методи математичної статистики. Ефективність запропонованої програми підтверджено достовірними позитивними змінами у досліджуваних показниках.

Ключові слова: особи похилого віку, деменція, когнітивні порушення, функціональні обмеження, фізичні вправи.

Вступ. Деменція визначається, як набуте стійке порушення когнітивних функцій внаслідок пошкодження мозку різної етіології, що проявляється розладами в двох чи більше когнітивних сферах (увага, пам'ять, мова, виконавчі функції та ін.) при нормальній свідомості і рівні бадьорості, що призводять до порушення побутової та соціальної взаємодії [11]. Одним iз дегенеративних неврологічних захворювань, яке спричиняє деменцію, є хвороба Альцгеймера.

Хвороба Альцгеймера (ХА) - це захворювання, при якому гинуть клітини головного мозку, що призводить до тяжких розладів пам'яті, інтелекту, інших когнітивних функції, а також до серйозних проблем в емоційно-особистісній сфері і поведінці [1].

На сьогодні хвороба Альцгеймера визнана однією 3 найбільш поширених причин старечого слабоумства (до 40\% всіх випадків) [2].

Обгрунтування дослідження. Статистичний аналіз медичної документації дозволяє виявити стабільно прогресуючу тенденцію до щорічного збільшення кількості хворих на Альцгеймера. Це пов'язано із швидкими темпами старіння населення, адже головним фактором ризику розвитку цієї недуги $\epsilon$ вік: на кожні 5 років після 65-річного віку показник ризику збільшується в 2 рази, підвищуючись від 3 випадків у 65 років до 69 випадків на 1000 чоловік в 95 [6]. Так, на початку 21 століття загальна кількість хворих, які страждали на деменцію, становила 24,3 млн.; 60,1\% цих людей жили в країнах, що розвиваються. Найбільша розповсюдженість деменції була в Азійсько-Тихоокеанському регіоні - 9,9 млн., тоді як у Свропі - 7,7 млн., у Північній та Південній Америці - 5,2 млн., а в Африці лише 1,5 млн. [4, 5].

$\mathrm{У}$ пацієнтів із хворобою Альцгеймера основними клінічними проявами захворювання є розвиток когнітивних (порушення пам'яті щодо недавніх подій, труднощі в запам'ятовуванні нової інформації, порушення мовлення та інтелекту, афазія, апраксія або агнозія), функціональних та поведінкових симптомів. Некогнітивні прояви деменції включають широке коло психопатологічних порушень різного рівня важкості, до яких належать: депресія, тривога, галюцинації, маячні ідеї, делірій, збудження, агресивна поведінка [7, 5].

На ініціальній стадії хвороби першою ознакою захворювання часто виявляється поступовий 
відхід людини від активної участі в житті. Відбувається звуження соціальної активності й інтересів, зниження кмітливості і розумової пристосовності, толерантності до нових ідей і повсякденних проблем [9]. Надалі починають наростати явища фіксаційної амнезії, порушення орієнтування в часі і місці. Виникають утруднення в розумових операціях, особливо в абстрактному мисленні, можливостях узагальнення і порівняння. З'являються і прогресивно посилюються порушення вищих кіркових функцій - мови, праксису, оптико-просторової діяльності. Наголошуються також виразні зміни особи у вигляді підвищеної збудливості, конфліктності, образливості, різко вираженого егоцентризму. В результаті цього мислення i активність хворого часто обертаються навколо самого себе і набувають дитячого характеру [9].

На сьогодні більша частина пацієнтів із хворобою Альцгеймера знаходиться під опікою рідних та близьких у домашніх умовахчерез відсутність в достатній кількості відповідних установ та нерозвиненість у нашій країні профільних служб, що забезпечують амбулаторний догляд. Одночасно 3 цим варто зазначити, що пацієнтам із різними формами деменції з метою когнітивної стимуляції та підвищення рівня функціональної активності необхідна постійна участь у структурованій групі із залученням фахівців мультидисциплінарної команди, адже вирішення проблем таких пацієнтів не може здійснювати фахівець лише одного профілю. Таким чином, враховуючи постійне зростання кількості хворих, потрібно звернути суттєву увагу на питання упровадження програм фізичної терапії у реабілітаційний процес пацієнтів похилого віку із хворобою Альцгеймера.

Мета: оцінити ефективність комплексної програми фізичної терапії осіб похилого віку з хворобою Альцгеймера.

Матеріали і методи: робота грунтується на оцінці впливу авторської програми фізичної терапії осіб похилого віку із хворобою Альцгеймера, яка включала ранкову гігієнічну гімнастику, лікувальну гімнастику, працетерапію та лікувальну дозовану ходьбу. Головними завданнями нашої програми були: підвищення рівня рухової активності хворих; підвищення рівня розвитку фізичних якостей (витривалості, сили м'язів, координації та гнучкості (амплітуди рухів), уповільнення прогресування когнітивних порушень, підвищення психоемоційного стану та зниження рівня перезбудження.

У дослідженні приймали участь 14 пацієнтів від 65 до 66 років з хворобою Альцгеймера (9 жінок та 5 чоловіків), які перебували на реабілітації в Комунальній установі Сумської обласної ради «Лебединський психоневрологічний інтернат». Із метою оцінки результативності впровадженої програми фізичної терапії були застосовані медико-біологічні методи: шкала MMSE або «Коротка шкала оцінки психічного статусу», шкала PAINAD, шкала «Оцінка рухової активності у осіб похилого віку». Математичну обробку отриманих даних здійснювали відповідно до алгоритму.

Результати дослідження та їх обговорення. Реабілітаційне втручання - це процес і система медичних, психологічних, педагогічних, соціальноекономічних заходів, спрямованих на усунення та компенсацію обмежень життєдіяльності, викликаних порушенням здоров'я із стійким розладом функцій організму, що є частиною щоденного догляду за хворим [10].

Для вирішення завдань дослідження в основу роботи покладено наступні методи: контент аналіз медичної документації (опрацювання результатів об'єктивних досліджень, протоколів обстежень, листів спостереження, результатів лабораторних аналізів осіб похилого віку 3 ХА, що занесені до історії хвороби); аналіз результатів клінічного обстеження хворих, серед них дані, отримані в ході збору анамнезу, огляду, пальпації, магнітно-резонансної томографії.

При аналізі анамнезу звертали увагу на вік, в якому вперше було виявлено симптоми хвороби Альцгеймера, періоди загострення і ремісії хвороби, реабілітаційні заходи, проведені раніше. Особливу увагу акцентували на скаргах, які висловлювали хворі, та на наявні супутні соматичні або неврологічні захворювання. При первинному знайомстві 3 хворими піддавали аналізу основні показники стану рухової сфери, що дозволяло охарактеризувати загальний стан статики і локомоції.

Медико-біологічні методи дослідження включали: оцінку орієнтації, пам'яті, уваги, здатності рахувати, мови; для візуального сприйняття тематичних хворих застосовувалася шкала MMSE або «Коротка шкала оцінки психічного статусу» [8]; для об'єктивної оцінки болю використовувалася шкала PAINAD (Оцінка болю при деменції тяжкого ступеня); для визначення рівня рухової активності осіб похилого віку, в тому числі для оцінки параметрів пересування, стійкості та балансу, була використана «Оцінка рухової активності у осіб похилого віку» (Functional mobility assessment in elderly patients) [3].

Обробка отриманих даних включала методи математичної статистики. Дослідження проводилися протягом 2018-2019 рр. на базі Комунальної установи Сумської обласної ради «Лебединський психоневрологічний інтернат». У дослідженні приймали участь 14 осіб похилого віку від 65 до 66 років з хворобою Альцгеймера (табл. 1).

Таблиця 1

Статево-віковий розподіл осіб похилого віку 3 хворобою Алыцгеймера у досліджуваних групах

\begin{tabular}{|l|l|l|l|l|}
\hline \multirow{2}{*}{$\begin{array}{c}\text { Групи } \\
\text { хворих }\end{array}$} & \multicolumn{2}{|c|}{ Вік } & \multicolumn{2}{c|}{ С5 } \\
\cline { 2 - 5 } & $\begin{array}{c}66 \\
\text { років }\end{array}$ & Жінки & Чоловіки \\
\hline $\begin{array}{l}\text { Всього } \\
n=14\end{array}$ & 6 & 8 & 9 & 5 \\
\hline
\end{tabular}

Для оцінки впливу комплексної програми фізичної терапії на когнітивні функції осіб з ХВ провели повторний тест «Коротка шкала оцінки психічного статусу» (шкала MMSE). Результати тесту оцінювали через суму результатів за кожним пунктом. Чим менший результат тесту, тим більш виражений когнітивний дефіцит. На початку дослідження у 3 пацієнтів досліджуваної групи наявною була демен- 
ція легкого ступеня вираженості (середній бал $20,2 \pm 1,52)$, у 4 інших - помірного ступеня вираженості (середній бал 18,1 $\pm 1,63$ ).

У результаті проведеного дослідження встановлено, що значних змін у покращенні когнітивних функцій не відбулося, що пов'язано 3 відсутністю занять психосоціальною реабілітацією або іiі не систематичністю у інтернаті, а також із незначним часом, відведеним на проведення дослідження в рамках написання кваліфікаційної роботи.
Наприкінці дослідження у 3 пацієнтів досліджуваної групи залишилася деменція легкого ступеня, але середній бал тесту покращився на 1,23 і в загальному вигляді становив $21,4 \pm 0,91$ бали. Та сама тенденція виявлена і в інших 4 пацієнтів 3 помірним ступенем вираження, у яких середній бал також покращився на 1,13 і становив 19,2 1,1 (табл. 2).

Оцінка впливу комплексної програми фізичної терапії на когнітивні функції хворих за тестом «Коротка шкала оцінки психічного статусу»

\begin{tabular}{|l|c|c|c|}
\hline Ступінь деменції & Кількість осіб (n) & $\begin{array}{c}\text { На початку } \\
\text { дослідження }\end{array}$ & У кінці дослідження \\
\hline Легкий ступінь деменції & 3 & $20,2 \pm 1,52$ & $21,4 \pm 0,91$ \\
\hline $\begin{array}{l}\text { Помірний ступінь } \\
\text { деменції }\end{array}$ & 4 & $18,1 \pm 1,63$ & $19,2 \pm 1,1$ \\
\hline
\end{tabular}

Після впровадження авторської програми було проведено порівняння оцінки болю за шкалою PAINAD. На показники цієї шкали ми орієнтувалися i під час реалізації програми, за рекомендацією науковця I. Пінчук. Це пов'язано з тим, що більшість хворих на деменцію не завжди можуть точно описати свої скарги. Саме тому ми стежили за зміною поведінкисвоїх пацієнтів під час занять протягом усього курсу. Це дозволяло проводити певний зв'язок між болем та іншими поведінковими і психопатологічними ознаками деменції, що проявляли хворі. Для оцінки болю ми протягом п'яти хвилин спостерігали за диханням, виразом обличчя, позами та рухами пацієнта, за звуками, що він видає, та аналізували наявність або відсутність потреби його втішати.

На початку дослідження за шкалою PAINAD середній ступінь болю було встановлено у всіх пацієнтів досліджуваної групи з загальним середнім балом 4,31 $\pm 0,83$. Після впровадження авторської комплексної програми фізичної терапії відмічено зменшення ступеня болю до $3,45 \pm 0,78$ і відповідно покращення досліджуваного показника на 0,83 . Це свідчить про зміну ступеня болю 3 середнього на легкий. Більш детально зміни за критеріями шкали PAINAD представлені у таблиці 3.

Результати оцінки ступеня болю за шкалою PAINAD на початку та у кінці дослідження

\begin{tabular}{|l|c|c|c|}
\hline Критерій оцінки & На початку дослідження & У кінці дослідження & Р \\
\hline Дихання & $0,42 \pm 0,11$ & $0,21 \pm 0,32$ & $\leq 0,05$ \\
\hline Вираз обличчя & $0,89 \pm 0,24$ & $0,44 \pm 0,48$ & $\leq 0,05$ \\
\hline Пози та рухи тіла & $0,76 \pm 0,15$ & $0,48 \pm 0,36$ & $\leq 0,05$ \\
\hline Негативні звуки & $0,81 \pm 0,17$ & $0,29 \pm 0,25$ & $\leq 0,05$ \\
\hline $\begin{array}{l}\text { Необхідність втіхи, } \\
\text { відволікання }\end{array}$ & $0,37 \pm 0,33$ & $0,72 \pm 0,17$ & $\leq 0,05$ \\
\hline
\end{tabular}

У ході дослідження було проведено оцінювання рухової активності осіб з хворобою Альцгеймера. Для оцінки параметрів пересування, стійкості та балансу, сили м'язів рук було використано шкалу «Оцінка рухової активності у осіб похилого віку». На початку дослідження вихідний рівень рухової активності усіх тематичних хворих, що проходили курс фізичної терапії, був приблизно однаковим i становив $29,7 \pm 1,5$ бали. Заняття РГГ, ЛГ та ЛДХ протягом 5 місяців сприяли підвищенню рівня загальної рухової активності до $30,4 \pm 0,7$ балів (рис. 1).
Відбулися позитивні зрушення і у рівні стійкості осіб похилого віку з хворобою Альцгеймера. Так, на початку дослідження загальний показник стійкості усіх тематичних хворих становив 14,3 $\pm 1,9$ балів, у кінці дослідження, після впровадження авторської комплексної програми фізичної терапії 19,2 $\pm 0,3$ бали (рис. 2).

Це свідчить про позитивний вплив занять лікувальною гімнастикою, в межах якої активно виконувалися вправи на покращення рівня рівноваги та координації. 


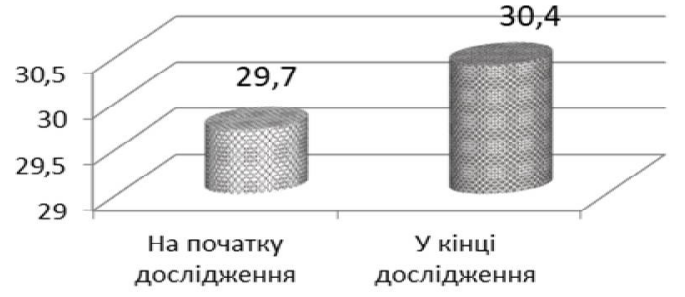

ж: На початку дослідження

ж кінці дослідження

Рис. 1. Оцінка загального рівня рухової активності осіб 3 хворобою Альцгеймера на початку та $\mathbf{y}$ кінці дослідження (у балах)

« На початку дослідження У

Рис. 2. Оцінка загального рівня стійкості у осіб із хворобою Альцгеймера на початку та у кінці дослідження (у балах)

У рамках тесту було проведено оцінки ходи осіб із хворобою Альцгеймера на початку та у кінці дослідження. Порівнюючи вихідний показник $14,0 \pm 0,5$ з підсумковим показником $18,7 \pm 1,1$, констатуємо покращення показника на 4,7 бали, $\mathrm{p}<0,05$ (рис. 3).
У ході дослідження проводилася оцінка стану м'язової системи у осіб похилого віку з ХА шляхом вимірювання сили кистей за допомогою динамометра. Цей показник дозволяє кількісно оцінити дефіцит у фізичному статусі пацієнта.

Вимірювання проводилися на різних руках 3 урахуванням гендерної різниці (табл. 4).

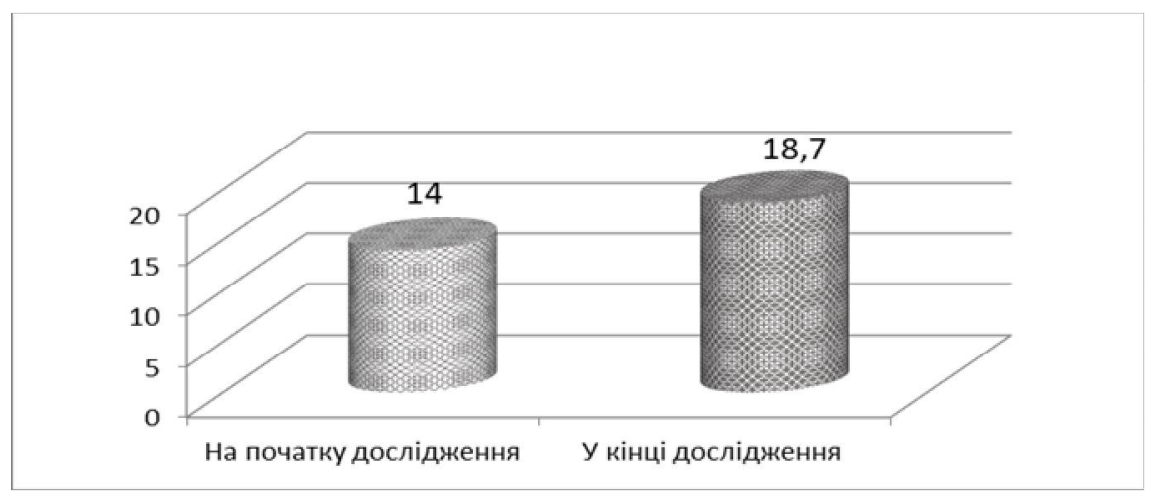

Рис. 3. Оцінка ходи в осіб із хворобою Альцгеймерана початку та у кінці дослідження (у балах)

Оцінка сили м'язів при кистьовій динамічній пробі у осіб похилого віку з ХА

\begin{tabular}{|c|c|c|c|c|}
\hline \multirow{2}{*}{$\begin{array}{c}\text { Етап } \\
\text { дослідження }\end{array}$} & \multicolumn{2}{|c|}{ Чоловіки } & \multicolumn{2}{c|}{ Жінки } \\
\cline { 2 - 5 } & $\begin{array}{c}\text { Сила } \\
\text { лівої руки (кг) }\end{array}$ & $\begin{array}{c}\text { Сила } \\
\text { правої руки (кг) }\end{array}$ & $\begin{array}{c}\text { Сила } \\
\text { лівої руки (кг) }\end{array}$ & $\begin{array}{c}\text { Сила } \\
\text { правої руки (кг) }\end{array}$ \\
\hline $\begin{array}{c}\text { На початку } \\
\text { дослідження }\end{array}$ & $22,4 \pm 0,9$ & $24,1 \pm 1,1$ & $17,1 \pm 1,3$ & $18,2 \pm 1,5$ \\
\hline У кінці дослідження & $22,6 \pm 1,6$ & $24,8 \pm 2,1$ & $17,6 \pm 1,0$ & $19,1 \pm 1,2$ \\
\hline
\end{tabular}

Так, показник сили правої руки у чоловіків

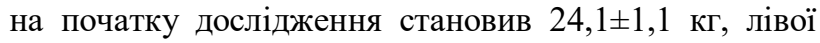
руки відповідно - 22,4 $\pm 0,9$ кг. Після проходження курсу фізичної терапії відбулися достовірні позитивні зміни показників сили рук чоловіків до наступних показників: сила правої руки - до $24,8 \pm 2,1$ кг, сила лівої руки - до 22,6士1,6 кг (рис.4).
Вимірювання сили кистей жінок на початку та у кінці дослідження також підтвердили ефективність впровадженої програми, про що свідчать наступні показники: сила правої руки на початку дослідження становила 18,2 1,5 кг, наприкінці до-

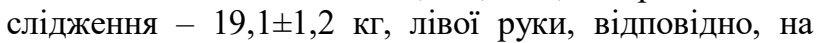
початку дослідження - 17,1 $\pm 1,3$ кг, у кінці дослідження - 17,6 $\pm 1,0$ кг (рис. 5). 

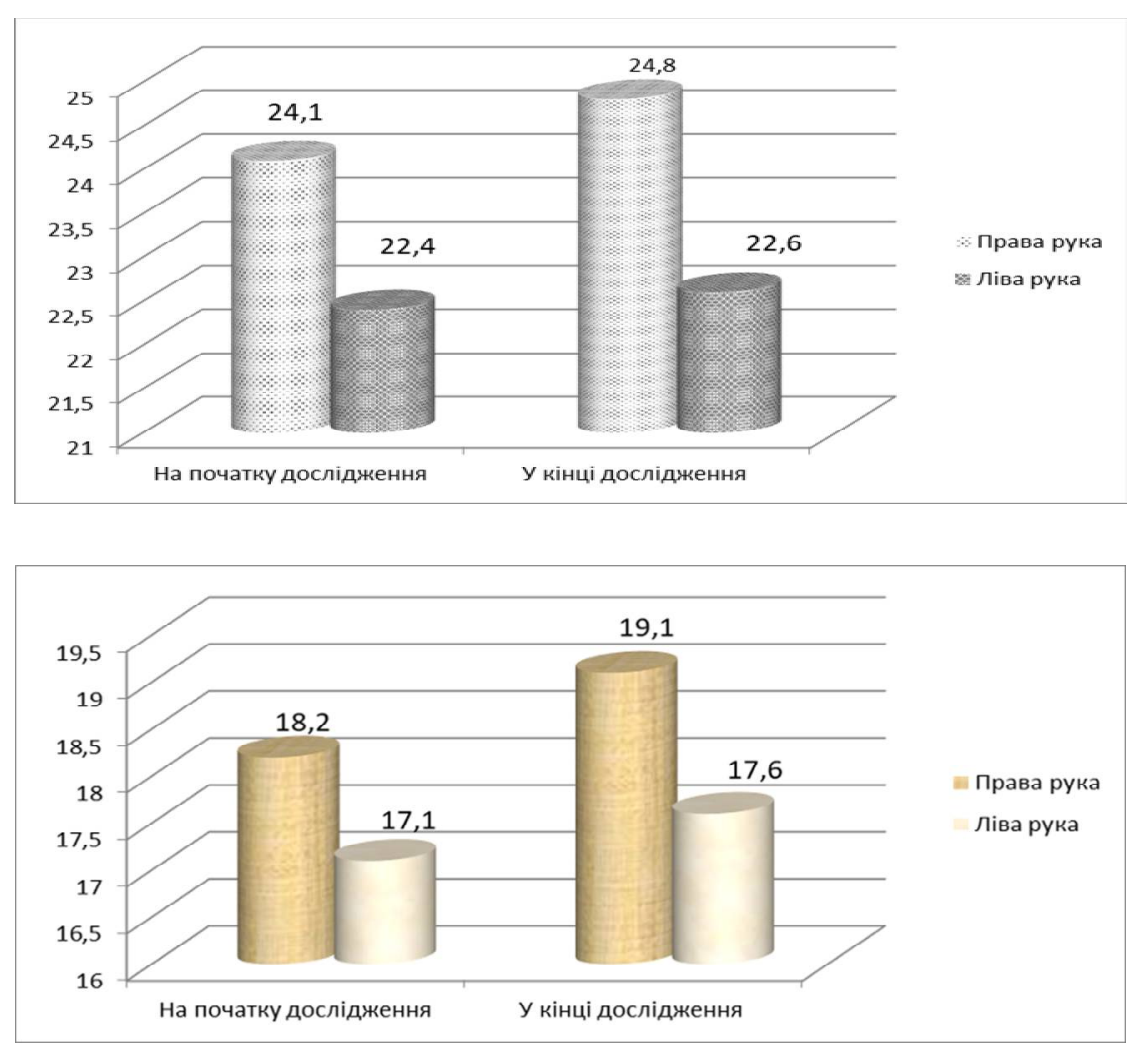

Рис. 4. Оцінка сили кистей чоловіків 3 XА на початку та у кінці дослідження (кг)

\author{
Рис. 5. Оцінка сили \\ кистей жінок 3 ХА на \\ початку та у кінці \\ дослідження (кг)
}

У чоловіків і жінок з ХА спостерігається достовірне збільшення показника динамометрії за показниками обох рук. Це підтверджує ефективність фізичних вправ, і відповідно, програми фізичної терапії, яка була запропонована цій групі хворих.

Висновки. Хвороба Альцгеймера - це дегенеративне захворювання мозку, в процесі розвитку якого клітини головного мозку дегенерують та гинуть, що призводить до прогресуючого порушення вищих психічних функцій, поведінки та фізичної активності людини. Хвороба Альцгеймера є однією із найпоширеніших причин деменції, яка проявляється у втраті інтелектуальних здібностей, професійних, соціальних та побутових навичок.

3 метою підвищення рівня фізичної активності, розвитку фізичних якостей та збереження рухових навичок осіб 3 хворобою Альцгеймера було розроблено, обгрунтовано та впроваджено у діяльність Комунальної установи Сумської обласної ради «Лебединський психоневрологічний інтернат» комплексну програму фізичної терапії, яка включала ранкову гігієнічну гімнастику, лікувальну гімнастику, працетерапію, лікувальну дозовану ходьбу. Авторська комплексна програма фізичної терапії реалізовувалася протягом 5 місяців, що було обумовлено науково обгрунтованими даними про те, що поліпшення якості життя осіб з хворобою Альцгеймера достовірно може відбутися лише через 3-6 місяців після початку реабілітаційних заходів. Ефективність запропонованої програми підтверджено достовірними позитивними змінами у показниках оцінки болю за шкалою PAINAD, оцінки параметрів пересування, стійкості, балансу, сили м'язів рук за шкалою «Оцінка рухової активності у осіб похилого віку».
Спостереження за хворими у кінці дослідження засвідчило покращення загального самопочуття осіб з хворобою Альцгеймера та підвищення їх психоемоційного стану. Не відбулося значних змін лише у показниках тесту «Коротка шкала оцінки психічного статусу» (або шкалі MMSE (Mini-mental State Examination), що ми пов'язуємо з відсутністю систематичних занять когнітивною реабілітацією, а також незворотністю самого процесу протікання захворювання.

\section{References:}

1. Mayeux R. Early Alzheimers Disease. New England Journal of Medicine. 2010; 362:2194-2201.

2. Nowotny P, Known J, Goate A. Encyclopediaoflifesciences. Nature Publishing Group www.els.net. 2001.

3. Park SK, Richardson CR, Holleman RG, Larson JL.Frailtyinpeoplewith COPD, usingthe National Healthand Nutrition Evaluation Surveydataset (2003-2006). 2013; 42(3):163-170.

4. Prince M, Wimo A, Guerchet M, Ali GC, Wu YT, Prina M. World Alzheimer Report. The Global Impactof Dementia. Alzheimers Disease International. Alzheimers Disease International. 2015; 3:23-24.

5. Rizzi L, Rosset Global I, Roriz-Cruz M. Epidemiologyof Dementia: Alzheimersand Vascular Types. BioMedResearch International. 2014; 2: 1-8. - Rezhym dostupu: https:/www.hindawi. com/journals/bmri/ 2014/908915/

6. Belova AN, PrusakovaZhB, Zagrekov VI, Ezhevskaya AA. Bolezn Alczgejmera i anesteziya. Uspekhi sovremennogo estestvoznaniya. 2015; 8:714. 
7. Dementsiia (vybrani polozhennia). Unifikovanyi klinichnyi protokol pervynnoi, vtorynnoi (spetsializovanoi), tretynnoi (vysokospetsializovanoi) tapaliatyvnoi medychnoi dopomohy. LikyUkrainy, 2017; 7(213):1-10.

8. Zastosuvannia molekuliarnykh tapsykhometrychnykh pokaznykiv dliau doskonalennia diahnostyky viddalenykh postradiatsiinykh kohnityvnykh rozladiv : metodychni rekomendatsii. Rezhymdostupu: http://nrcrm.gov.ua/downloads/mr 149.pdf

9. Kozolkin OA, Sikorska MV, Vizir IV, NerianovaYuM. Dementsiia : navchalno-metodychnyi posibnyk. Zaporizhzhia : [ZDMU]. 2015. P.90.

10. Ridkovets TH, Alia Omar Samara, Mekhdi Abolfatkhi. Zasoby fizychnoi reabilitatsii $\mathrm{v}$ terapii osib $\mathrm{z}$ rozsiianymsklerozom. Pedahohika, psykholohiiata medyko-biolohichni problemy fizychnoho vykhovannia i sportu : zbirnyk naukovykh prats. Kharkiv. 2009; 6:126-131.

11. Romaniv OP, Chorei DV. Osoblyvosti kohnityvnoi reabilitatsii patsiientiv $\mathrm{z}$ dementsiieiu. Ekonomika i pravookhoronyzdorovia. 2018;1(7):17-22.

\section{УДК 378.147: [615.825 + 615.851.3] -051 \\ РЕЗУЛЬТАТЫ ВНЕДРЕНИЯ ПРОГРАММЫ ФИЗИЧЕСКОЙ ТЕРАПИИ ЗА ПОКАЗАТЕЛЯМИ ПОЖИЛЫХ ЛЮДЕЙ С БОЛЕЗНЬЮ АЛЬЦГЙМЕРА}

О.А. Беспалова, Ю.О. Лянной, Т.В. Бугаенко, О.В. Лянная, Н.Б. Авраменко

Сумской государственный педагогический университет им. А.С. Макаренко,

кафедра здоровья, физической терапии, реабилитациии и эрготерапии,

2.Сумы,, Украина,

ORCIDID: 0000-0002-0081-6021,

e-mail: i-ozon777@bigmir.net,

ORCID ID: 0000-0003-2332-8794,

e-mail:lyo_ifk@ukr.net,

ORCID ID: 0000-0003-3745-0593,

e-mail:bugaenkotv@ukr.net,

ORCID ID: 0000-0002-4467-7166,

e-mail:lann_olga@ukr.net,

ORCID ID: 0000-0002-1894-7345,

e-mail:avram2104@gmail.com

Резюме. Деменция - это повреждения мозга в результате различных травм и заболеваний, которое приводит к стойким нарушениям когнитивных и двигательных функций. Одним из дегенеративных неврологических заболеваний, которое вызывает деменцию, является болезнь Альцгеймера. С целью эффективного реабилитационного вмешательства необходима профессиональная помощь специалистов мультидисциплинарной команды, где специалистам по физической терапии, эрготерапии принадлежит одно из ведущих мест. Задачами физической терапии, эрготерапии, касающихся лиц с болезнью Альцгеймера, являются: повышение уровня их физической активности, развитие главных физических качеств, сохранение бытовых двигательных навыков и улучшение психоэмоционального состояния. С этой целью была разработана, научно обоснована и внедрена в деятельность Коммунального учреждения Сумского областного совета «Лебединский психоневрологический интернат» комплексная программа физической терапии, эрготерапии, в которую было включено утреннюю гигиеническую гимнастику, лечебную гимнастику, трудотерапию и лечебную дозированную ходьбу. Реализация авторской программы происходила в течение 5 месяцев, что обусловлено научно обоснованными данными о том, что улучшение качества жизни лиц с болезнью Альцгеймера, достоверно может состояться только через 3-6 месяцев после начала реабилитационных мероприятий. В исследовании использовались методы: контент-анализ медицинской документации; педагогические - наблюдение, медико-биологические: шкала MMSE, шкала PAINAD, шкала «Оценка двигательной активности у лиц пожилого возраста»; методы математической статистики. Эффективность предложенной программы подтверждено достоверными положительными изменениями в исследуемых показателях.

Ключевые слова: престарелые, деменция, когнитивные нарушения, функциональные ограничения, физические упражнения.

\section{UDC 378.147: [615.825 + 615.851.3] -051 \\ PHYSICAL THERAPY PROGRAM IMPLEMEN- TATION RESULTS ON THE INDICATORS OF ELDERLY PEOPLE WITH ALZHEIMER'S DISEASE}

O.O. Bespalova, Yu.O. Liannoi, T.V. Bugaenko, O.V. Lianna, N.B. Avramenko

Sumy State Pedagogical University named after A. S. Makarenko, Department of Health, Physical Therapy, Rehabilitation and Ergotherapy,

Sumy, Ukraine,

ORCID ID: 0000-0002-0081-6021,

e-mail: i-ozon777@bigmir.net,

ORCID ID: 0000-0003-2332-8794,

e-mail:lyo_ifk@ukr.net,

ORCID ID: 0000-0003-3745-0593,

e-mail: bugaenkotv@ukr.net,

ORCID ID: 0000-0002-4467-7166,

e-mail:lann_olga@ukr.net,

ORCID ID:-0000-0002-1894-7345,

e-mail:avram2104@gmail.com

Abstract. Dementia is a brain injury due to various traumas and diseases that leads to acquired persistent impairments of cognitive and motor functions. As a result, the person loses the opportunity to continue to perform professional, social and household duties, to live a fulfilling life. One of the degenerative neurological diseases that causes dementia is Alzheimer's disease. For the purpose of effective rehabilitation intervention aimed at cognitive stimulation, maintaining the level of physical activity and improving the quality of life of patients, 
professional assistance of specialists of a multidisciplinary team is needed, where one of the leading places belongs to specialists in physical therapy and ergotherapy. Physical therapy, ergotherapy of the elderly with Alzheimer's disease should be aimed at increasing their level of physical activity, development of major physical qualities (general endurance, muscle strength, coordination and balance, fine motor skills), and preservation of everyday motor skills and improvement of psychoemotional state. For this purpose, a comprehensive program of physical therapy, ergotherapy, which included morning hygienic gymnastics, medical gymnastics, and occupational therapy, was developed, scientifically substantiated and implemented in the activities of the Municipal Institution of the Sumy Regional Council «Lebedyn Psychoneurological Centre». The studies were conducted during October-March 2018-2019. The study involved 14 elderly people aged 65 to 66 years with Alzheimer's disease, including 9 women and 5 men. The implementation of the author's program took place within 5 months, which was conditioned by scientifically substantiated data that the improvement of the quality of life of persons with Alzheimer's disease can only improve significantly after 3-6 months after the beginning of rehabilitation activities. The following research methods were used in the organization and conduct of the study: content analysis of medical records (results of objective studies, survey reports, observation sheets, laboratory test results) pedagogical - establishment and formation of experiments, observations, medical and biological methods. The latter included assessment of orientation, memory, attention, ability to count, language, and visual perception of thematic patients were used on the MMSE scale or the «Short Scale of Mental Status Assessment». The PAINAD (Severe Dementia Pain Scale) was used for objective pain assessment; Functional mobility assessment in elderly patients was used to determine the level of motor activity of the elderly, including the estimation of movement parameters, stability and balance; psychological and pedagogical: conversations; methods of mathematical statistics. The effectiveness of the proposed physical therapy program was confirmed by significant positive changes in PAINAD pain scores, assessment of movement parameters, coordination abilities: stability and balance, arm muscle strength on the Scale of motor activity in the elderly. Observation of patients at the end of the study showed an improvement in the general wellbeing of persons with Alzheimer's disease and an increase in their emotional state. There were no significant changes only in the indicators of the Short Scale of Mental Status Test (or the MMSE (Mini-mental State Examination) scale, which is attributed to the lack of systematic cognitive rehabilitation classes and the irreversibility of the disease process itself.

Keywords: the elderly, dementia, cognitive impairment, functional limitations, physical exercise. 